\title{
APPROXIMATION OF SOLUTIONS TO THE BOUNDARY VALUE PROBLEMS FOR THE GENERALIZED BOUSSINESQ EQUATION
}

\author{
V.Z. Furaev ${ }^{1,2}$, A.I. Antonenko ${ }^{1}$ \\ Novokuznetsk Institute (branch) Kemerovo State University, Novokuznetsk, \\ Russian Federation \\ South Ural State University, Chelyabinsk, Russian Federation \\ E-mail: kafmfimo@mail.ru
}

\begin{abstract}
The paper is devoted to one of the Sobolev type mathematical models of fluid filtration in a porous layer. Results that allow to obtain numerical solutions are significant for applied problems. We propose the following algorithm to solve the initial-boundary value problems describing the motion of a free surface filtered in a fluid layer having finite depth. First, the boundary value problems are reduced to the Cauchy problems for integrodifferential equations, and then the problems are numerically integrated. However, numerous computational experiments show that the algorithm can be simplified by replacing the integro-differential equations with the corresponding approximating Riccati differential equations, whose solutions can also be found explicitly. In this case, the numerical values of the solution to the integro-differential equation are concluded between successive values of approximating solutions. Therefore, we can pointwise estimate the approximation errors. Examples of results of numerical integration and corresponding approximations are given.

Keywords: Sobolev type equation; boundary value problem; integro-differential equation; free surface; Riccati equation.
\end{abstract}

Consider a fluid filtration in a porous layer having finite depth with a free surface $u=u(x, t)$. It is necessary to solve initial boundary value problems for the equation [1]

$$
u_{t}=\alpha\left(u^{2}\right)_{x x}+u_{t x x}, \quad 0<x<1, t>0,
$$

with boundary conditions

$$
u(0, t)=h(t) \geq 0, u(1, t)=H(t) \geq 0, \quad t \geq 0, \quad \alpha>0 ; \quad \alpha=\text { const },
$$

and the following initial condition coordinated with them

$$
u(x, 0)=u_{0}(x) \geq 0, u_{0}(0)=h(0), \quad u_{0}(1)=H(0)
$$

or with boundary conditions of the second kind

$$
\begin{aligned}
& \frac{\partial}{\partial x}\left(u_{t}+\alpha u^{2}\right)_{\mid x=0}=-h_{0}(t), \\
& \frac{\partial}{\partial x}\left(u_{t}+\alpha u^{2}\right)_{\mid x=1}=h_{1}(t),
\end{aligned}
$$

which define a fluid flow through the filtration region boundary. The problem (1) - (3) is called the first boundary value problem, and the problem (1), (2), (4) is called the 
second boundary value problem. The equation (1) is a Sobolev type equation. The initialboundary value problems for analogous equations were investigated in [2-5]. Introduce a function $v(x, t)=u_{t}+\alpha u^{2}$, write the equation (1) in the form $v-v_{x x}=\alpha u^{2}$, and invert the operator $1-\frac{\partial^{2}}{\partial x^{2}}$. Then, we have the Cauchy problems for the following integro-differential equations:

$$
\begin{gathered}
u_{t}(x, t)+\alpha \cdot u^{2}(x, t)=\alpha \cdot \int_{0}^{1} G_{1}(x, \xi) \cdot u^{2}(\xi, t) d \xi+\alpha \cdot\left(\frac{\operatorname{sh}(1-x)}{\operatorname{sh} 1} h^{2}+\frac{\operatorname{sh} x}{\operatorname{sh} 1} H^{2}\right), \\
u_{t}(x, t)+\alpha \cdot u^{2}(x, t)=\alpha \cdot \int_{0}^{1} G_{2}(x, \xi) \cdot u^{2}(\xi, t) d y+h_{0} \frac{\operatorname{ch}(1-x)}{\operatorname{sh} 1}+h_{1} \frac{\operatorname{ch} x}{\operatorname{sh} 1}
\end{gathered}
$$

with the initial condition (3), where

$$
\begin{aligned}
& G_{1}(x, \xi)=\frac{1}{\operatorname{sh} 1}\left\{\begin{array}{l}
\operatorname{sh} x \cdot \operatorname{sh}(1-\xi), 0 \leq x \leq \xi, \\
\operatorname{sh} \xi \cdot \operatorname{sh}(1-x), \xi \leq x \leq 1,
\end{array}\right. \\
& G_{2}(x, \xi)=\frac{1}{\operatorname{sh} 1}\left\{\begin{array}{l}
\operatorname{ch} x \cdot \operatorname{ch}(1-\xi), 0 \leq x \leq \xi, \\
\operatorname{ch} \xi \cdot \operatorname{ch}(1-x), \xi \leq x \leq 1
\end{array}\right.
\end{aligned}
$$

are the Green functions of the corresponding boundary value problems.

If the boundary conditions are stationary, i.e. the functions $h(t) \equiv h, H(t) \equiv H$, $h_{0}(t) \equiv 0, h_{1}(t) \equiv 0$ are constants, then the solutions to the considered boundary value problems converge to stationary solutions of the considered boundary value problems $[6$, 7] uniformly with respect to $x$ as $t \rightarrow \infty$.

The stationary solutions have the following form:

1) $U_{1}(x)=\sqrt{\left(H^{2}-h^{2}\right) x+h^{2}}$ is the Dupuy parabola,

2) $U_{2}(x)=\int_{0}^{1} u_{0}(x) d x$ is the law of mass conservation in the case of impermeability of the boundary or zero total flow through the boundaries of the filtration region, respectively for the first and second boundary value problems.

In order to obtain approximate solutions and construct profiles of free surfaces of a filtered fluid, we propose to replace the integro-differential equations (5) and (6) with the approximating Riccati equations

$$
u_{1 t}+\alpha u_{1}^{2}=\alpha U_{1}^{2}
$$

and

$$
u_{2 t}+\alpha u_{2}^{2}=\alpha U_{2}^{2},
$$

respectively. Their solutions that satisfy the initial condition (3) can be found explicitly and have the form:

$$
u_{n}(x, t)=\frac{u_{0}(x)+U_{n} \cdot \operatorname{th}\left(\alpha \cdot U_{n} \cdot t\right)}{1+\frac{u_{0}(x)}{U_{n}} \cdot \operatorname{th}\left(\alpha \cdot U_{n} \cdot t\right)}, \quad n=1,2 .
$$

Further, the implementation of this method for specific initial conditions is carried out in the MATHCAD. The free surface profiles form one-parameter family of curves in the plane. 
Consider some examples of profile construction using the numerical integration of the equations (5) and (6) in comparison with the graphs of solutions to the corresponding equations (7) and (8), where we can observe a difference in the values of the solutions because of the approximations.

Example 1. Consider the first boundary value problem (1) - (3) for $h=1$ and $H=4$. Calculation formulas for numerical integration of the equation (5) and the coordinates of points of the function (9) graphs have the form, respectively:

$$
\begin{gathered}
u_{k+1, i}=u_{k, i}-\alpha\left[\left[u_{k, i}^{2}-\sum_{j=0}^{N}\left(G_{1 i, j} \cdot u_{k, j}^{2} \cdot \Delta x\right)\right]-\frac{\operatorname{sh}(1-i \cdot \Delta x)}{\operatorname{sh} 1} h^{2}-\frac{\operatorname{sh}(i \cdot \Delta x)}{\operatorname{sh} 1} H^{2}\right] \cdot \Delta t, \\
w_{k, i}=\frac{u_{0}(i \cdot \Delta x)+U_{1, i} \cdot \operatorname{th}\left(\alpha \cdot U_{1, i} \cdot k \cdot \Delta t\right)}{1+\frac{u_{0}(i \cdot \Delta x)}{U_{1, i}} \operatorname{th}\left(\alpha \cdot U_{1, i} \cdot k \cdot \Delta t\right)},
\end{gathered}
$$

where $U_{1, i}=\sqrt{\left(H^{2}-h^{2}\right) \cdot i \cdot \Delta x+h^{2}}$. In this case, if $0 \leq u_{0}(x) \leq U_{1}(x)$, then $w_{k, i} \leq u_{k+1, i} \leq w_{k+1, i}$ and as an approximate value $u_{k+1, i}$ we can take $u_{k+1, i}=$ $\frac{w_{k, i}+w_{k+1, i}}{2}$. Graphs of approximate solution to the problem $(5),(7)$ are shown in Fig. 1.

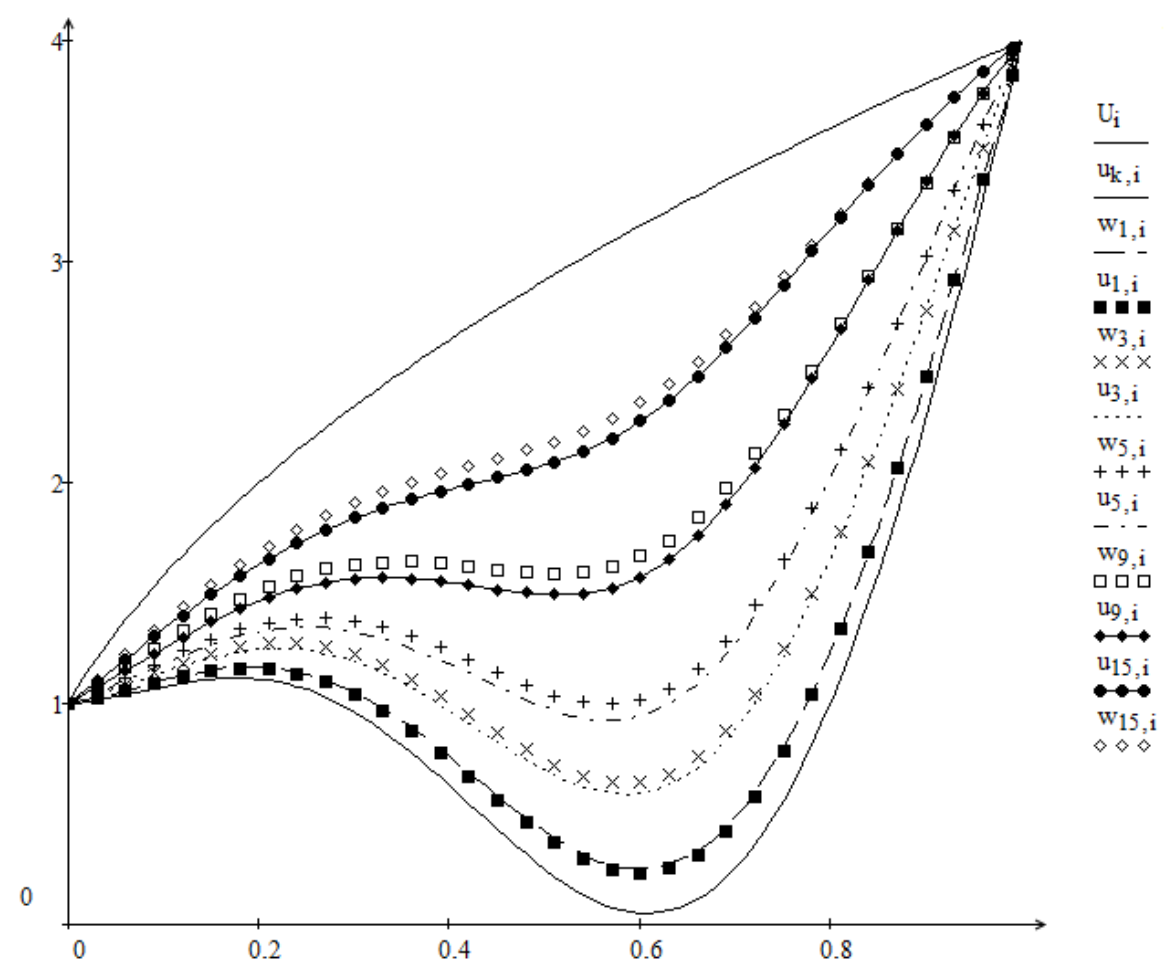

Fig. 1. Graphs of the solutions to the equations (5) (solid lines) and (7) (dashed lines) with the initial condition $u_{0}(x)=(3 x-1)^{2}+\sin 2 \pi x$. The upper curve is a graph of the stationary solution, the lower curve is a graph of the initial function $u_{0}(x), \alpha=0,8, \Delta x=$ $0,01, \Delta t=0,025$ 
Example 2. Consider the second boundary value problem (1), (2), (4). Calculation formulas for numerical integration of the equation (6) have the form:

$$
u_{k+1, i}=u_{k, i}-\alpha\left[u_{k, i}^{2}-\sum_{j=0}^{N}\left(G_{2 i, j} \cdot u_{k, j}^{2} \cdot \Delta x\right)\right]^{2} \cdot \Delta t .
$$

Graphs of approximate solution to the problem (6), (8) are shown in Fig. 2.

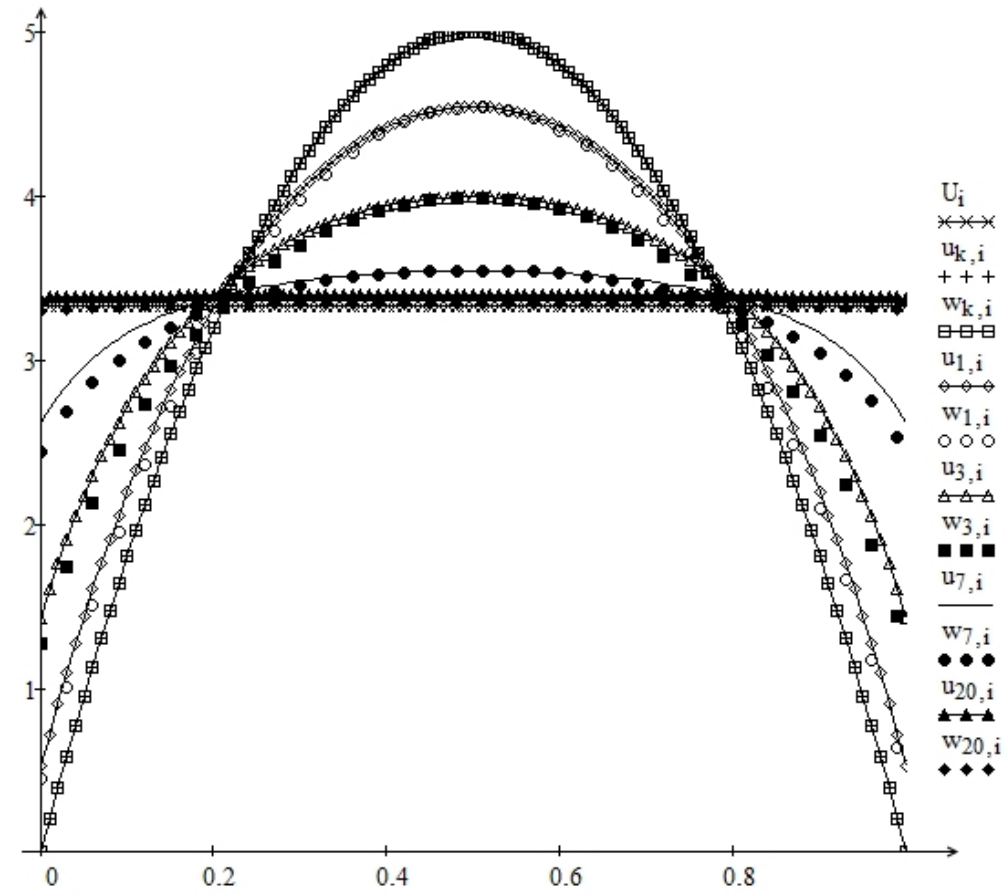

Fig. 2. The graphs of the solutions to the equations (6) and (8) with the initial condition $u_{0}(x)=-20\left(x^{2}-x\right)$, and $U_{2}=\int_{0}^{1} u_{0}(x) d x=3,33 \ldots, \Delta x=0,01, \Delta t=0,05$

Acknowledgements. The work was supported by Act 211 Government of the Russian Federation, contract No. 02.A03.21.0011.

\section{References}

1. Dzektser E.S., Shadrin G.A. [On the Motion of Groundwater with a Free Surface], Promyshlennoe i Grazhdanskoe Stroitelstvo [Industrial and Civil Engineering], 1971, vol. 10, pp. 22-44. (in Russian)

2. Sviridyuk G.A., Manakova N.A. The Barenblatt - Zheltov - Kochina Model with Additive White Noise in Quasi-Sobolev Spaces. Journal of Computational and Engineering Mathematics, 2016, vol. 3, no. 1, pp. 61-67.

3. Sviridyuk G.A., Manakova N.A. The Phase Space of the Cauchy-Dirichlet Problem for the Oskolkov Equation of Nonlinear Filtration. Russian Mathematics (Izvestiya VUZ. Matematika), 2003, no. 9, pp. 33-38. 
4. Zamyshlyaeva A.A., Bychkov E.V., Tsyplenkova O.N. Mathematical Models Based on Boussinesq - Love Equation. Applied Mathematical Sciences, 2014, vol. 8, no. 110, pp. $5477-5483$.

5. Sviridyuk G.A. A Problem for the Generalized Boussinesq Filtration Equation. Soviet Mathematics (Izvestiya VUZ. Matematika), 1989, vol. 33, no. 2, pp. 62-73.

6. Furaev V.Z. O razreshimosti kraevykh zadach i zadach Koshi dlya obobshchennogo uravneniya Bussineska $v$ teorii nestatsionarnoy fil'tratsii [On the Solvability of Boundary Value Problems and Cauchy Problems for the Generalized Boussinesq Equation in the Theory of Nonstationary Filtration. The dissertation of the candidate physical and mathematical sciences], Moscow, The Peoples' Friendship University named Patrice Lumumba, 1983. (in Russian)

7. Furaev V.Z. [Solvability in the Large of the First Boundary Value Problem for the Generalized Boussinesq Equation]. Differential Equations, 1983, vol. 19, no 11, pp. 2014-2015. (in Russian)

Received October 22, 2017

DOI: $10.14529 / \mathrm{mmp} 170414$

\title{
АППРОКСИМАЦИЯ РЕШЕНИЙ КРАЕВЫХ ЗАДАЧ ДЛЯ ОБОБЩЕННОГО УРАВНЕНИЯ БУССИНЕСКА
}

\author{
В.3. Фураев ${ }^{1,2}$, А.И. Антоненко ${ }^{1}$ \\ ${ }^{1}$ Новокузнецкий институт (филиал) Кемеровского государственного университета, \\ г. Новокузнецк, Российская Федерация \\ ${ }^{2}$ Южно-Уральский государственный университет, г. Челябинск, \\ Российская Федерация
}

\begin{abstract}
Работа посвящена одной из математических моделей соболевского типа фильтрации жидкости в пористом слое. В решении прикладных задач значимыми являются результаты, позволяющие получать их численные решения. Предлагается алгоритм решения начально-краевых задач, описывающих движение свободной поверхности фильтрующейся в слое конечной глубины жидкости: краевые задачи сводятся к задаче Коши для интегро-дифференциальных уравнений, а затем производится их численное интегрирование. Однако, как показывают многочисленные вычислительные эксперименты, указанный алгоритм можно упростить, заменяя интегро-дифференциальные уравнения аппроксимирующими их соответствующими дифференциальными уравнениями Риккати, решения которых может быть найдено также и в явной форме. При этом численные значения решения интегро-дифференциального уравнения заключены между последовательными по времени значениями аппроксимирующими их решениями, что позволяет произвести поточечную оценку погрешностей аппроксимации. Приводятся примеры результатов численного интегрирования и соответствующих аппроксимаций.
\end{abstract}

Ключевые слова: уравнения соболевского типа; краевые задачи; интегродифференциальное уравнение; свободная поверхность; уравнение Риккати. 


\section{Литература}

1. Дзекцер, Е.С. О движении грунтовых вод со свободной поверхностью / Е.С. Дзекцер, Г.А. Шадрин // Промышленное и гражданское строительство. - 1971. - Т. 10. - С. 22-44.

2. Sviridyuk, G.A. The Barenblatt - Zheltov - Kochina Model with Additive White Noise in Quasi-Sobolev Spaces // G.A. Sviridyuk, N.A. Manakova / Journal of Computational and Engineering Mathematics. - 2016. - V. 3, № 1. - P. 61-67.

3. Свиридюк, Г.А. Фазовое пространство задачи Коши - Дирихле для уравнения Осколкова нелинейной фильтрации // Г.А. Свиридюк, Н.А. Манакова / Известия высших учебных заведений. Математика. - 2003. - № 9. - С. 36-41.

4. Zamyshlyaeva, A.A. Mathematical Models Based on Boussinesq - Love Equation // A.A. Zamyshlyaeva, E.V. Bychkov, O.N. Tsyplenkova / Applied Mathematical Sciences. 2014. - V. 8, № 110. - P. 5477-5483.

5. Свиридюк, Г.А. Одна задача для обобщенного фильтрационного уравнения Буссинеска/ Г.А. Свиридюк // Известия высших учебных заведений. Математика. - 1989. - № 2. C. $55-61$.

6. Фураев, В.3. О разрешимости краевых задач и задач Коши для обобщенного уравнения Буссинеска в теории нестационарной фильтрации: дис. ... канд. физ.-мат. наук / B.З. Фураев. - М.: Ун-т дружбы народов им. П. Лумумбы, 1983.

7. Фураев, В.З. О разрешимости в целом первой краевой задачи для обобщенного уравнения Буссинеска / В.З. Фураев // Дифференциальные уравнения. - 1983. - Т. 19, № 11. C. $2014-2015$.

Валерий Зиновьевич Фураев, кандидат физико-математических наук, доцент, кафедра «Математика, физика и методика обучения», Новокузнецкий институт (филиал) Кемеровского государственного университета (г. Новокузнецк, Российская Федерация); научно-исследовательская лаборатория «Неклассические уравнения математической физики», Южно-Уральский государственный университет (г. Челябинск, Российская Федерация), kafmfimo@mail.ru.

Александр Иванович Антоненко, кандидат физико-математических наук, доцент, кафедра «Математика, физика и методика обучения», Новокузнецкий институт (филиал) Кемеровского государственного университета (г. Новокузнецк, Российская Федерация), kafmfimo@mail.ru.

Поступила в редакцию 22 октября 2017 г. 